\title{
Research the necessary code of conduct of Vietnamese students to integrate with the working and studying environment in Japan
}

\author{
Nguyen Tan DANH ${ }^{1}$ \\ ${ }^{1}$ FPT University, Vietnam, Email: nguyentandanh0774@gmail.com \\ * Corresponding Author
}

\author{
Received: 25.09.2021 Accepted: 23.12.2021 Published: 01.02.2022 $\quad$ DOI: 10.47750/QAS/23.186.36
}

\begin{abstract}
In recent years, the number of Vietnamese students studying and working in Japan has increased dramatically, but most of them often fall into culture shock and find it difficult to integrate because they do not understand the code of conduct of the local people. Understood as ethical, aesthetic, beliefs and rules governing human behavior in specific situations and circumstances, codes of conduct are highly important and especially necessary. It is essential in the integration issue for Vietnamese students who are or plan to study and work in Japan, a country where people attach great importance to politeness and manners in the working environment and in life itself. This article is completed from the results of comparing and contrasting research, previous and current documents, combined with actual surveys and interviews. The research results show that the code of conduct is a beauty that needs to be maintained, a necessary factor to help Vietnamese students integrate and adapt better to the working environment in Japan and improve the quality of studying and working in the land of the rising sun.
\end{abstract}

Keywords: Code of conduct, Japan, Vietnamese students, working environment

\section{Introduction}

Behavioral culture has existed for thousands of years and is constantly being improved. As the world began to divide into many continents, many countries and cultures became more and more diverse as the climate, topography, religion and social conditions in each country were different, which created additional codes of conduct for those countries. In a culture with a culture of conduct includes rules and standards that make people know what to do and what to avoid in social communication. Japan is a country that attaches great importance to these little things. These seemingly small and seemingly innocuous things have the potential to greatly affect whether a person succeeds or not at work. An ill-timed joke or disrespectful gesture can be seen as uncultured. Then, from a country extremely poor in terms of resources and suffering from repeated natural disasters, Japan rose to become the third developed economy in the world. It is the meticulousness that has become the brand that Vietnamese students have always considered the Japanese to be difficult (Lee, 2017). So are they really as tough as we think? This study will talk about the codes of conduct that have created the characteristics of Japanese people in the learning and working environment with the behavioral cultures in Vietnam, thereby combining and helping Vietnamese students who are or plan to study and work in Japan better understand the art of human behavior in the land of the rising sun to better adapt to the new working environment (Murphy \& Shigematsu, 2002)

\section{Research history}

Author Nguyet (2020) believes that behavioral culture is a part of school culture, which can have a good or bad influence on all activities of individuals or groups in the school environment. Made up of "self-expectations" and "positive rules to form a stable learning environment". Quang \& Ha (2018) pointed out that behavioral culture is concretized through the way we treat objects and also through the interaction between people. Thuong (2017) refers to behavioral culture as a combination of ways of living with its expression that mankind has created to adapt to the needs of life and the requirements of survival. Author Nha (2002) again confirmed that behavioral culture includes ethical, aesthetic and normative standards that help people understand whether to do this or not. It is an everyday culture, but it is necessary and more important than the sublime and profound things.

\section{The status of foreign students in Japan}

\subsection{General status of students in Japan}

According to author Lee (2017) Japan is the sixth most popular destination among the ideal study abroad destinations for international students in Western countries. Although Western students are quite picky largely due to the huge difference between Eastern and Western cultures, Japan is the top destination, in Asia alone. However, that does not mean that Japan is a dream destination for all students in Asia. Research by Murphy \& Shigematsu (2002) in analyzing the psychology of Korean students in Japan shows that they feel 


\section{GENERAL MANAGEMENT}

discriminated against by the Japanese because they do not understand the behavior of the people here. Korean students consider Japanese people's way of thinking and behavior to be closed, which hinders their overall quality of life and study in Japan (Tan, 2019). The above study shows that the inability to adapt to Japanese behavior causes many difficulties for international students.

\subsection{Status of Vietnamese students in Japan}

Studying and working in Japan is no longer a strange concept to Vietnamese students. In recent years, the number of Vietnamese studying Japanese in Japan has increased significantly. Notably, according to a survey in 2013, the number of Vietnamese studying Japanese in Japan was 18,633 , second only to the Chinese. Japan and Vietnam are two countries with many similarities in Eastern culture. Therefore, Vietnamese students studying in the land of cherry blossoms will quickly integrate into the environment. However, when Vietnamese students come to Japan, they tend to think very clearly that they like to stay with Vietnamese people to avoid foreign countries; when they are sick, they have each other by their side. Japanese friends do not play with them, so they do not understand the behavior of local people. Every day outside of language learning time, students go home to the market to cook rice. Life is no different in Vietnam, so my ability to adapt to the new environment is very limited.

\section{Research Methods, Scope and Objects}

This study is based on references in recent years. Through research methods including qualitative and quantitative methods combined with analytical methods to find out the characteristics of behavioral culture in Japan and the method of synthesizing from books and reference materials on Japanese culture. Japanese culture through a survey of nearly 30 students about the necessary behavioral cultures for Vietnamese students with the aim to create opportunities, supplement, raise awareness as well as cultivate necessary skills for students who intend to work in a Japanese environment or for Japanese language students who want to learn more about Japanese culture and behavior.

\section{Research Results and Discussion}

Code of conduct has become a feature of Japanese people in daily life and work (Nha, 2002). Understanding the code of conduct creates a massive advantage for international students in many fields, especially when looking for a job in Japan as shown in the table below (Table 1).

\begin{tabular}{|l|l|l|l|l|l|l|l|l|}
\hline Benefits and Disadvantages & $\mathbf{1}$ & $\mathbf{2}$ & $\mathbf{3}$ & $\mathbf{4}$ & $\mathbf{5}$ & Total & $\begin{array}{l}\text { Total } \\
\text { Score }\end{array}$ & $\begin{array}{l}\text { Average } \\
\text { Level }\end{array}$ \\
\hline $\begin{array}{l}\text { 1. The importance of understanding a } \\
\text { country's culture }\end{array}$ & 0 & 0 & 0 & 7 & 16 & 23 & 108 & 0.26 \\
$\begin{array}{l}\text { 2. Help increase your chances of getting a } \\
\text { job in Japan }\end{array}$ & 0 & 0 & 2 & 8 & 13 & 23 & 103 & 0.25 \\
\hline $\begin{array}{l}\text { 3. Vietnamese international students should } \\
\text { learn about behavioral culture first before } \\
\text { coming to Japan }\end{array}$ & 0 & 0 & 0 & 8 & 15 & 23 & 107 & 0.26 \\
\hline $\begin{array}{l}\text { 4. Not understanding the behavior culture } \\
\text { causes culture shock and misunderstanding }\end{array}$ & 0 & 0 & 5 & 10 & 8 & 23 & 95 & 0.23 \\
\hline Total
\end{tabular}

Table 1: Impact of Code of Conduct in Japan

Based on the questions mentioned in the table above (Table 1), all received many agreements from the respondents. The fact that question number 2 is widely accepted proves the importance of a code of conduct when looking for a job. Vietnamese international students are also encouraged to learn the code of conduct before coming to Japan (sentence 3) to avoid unfortunate things like in sentence 4. However, when coming to Japan, Vietnamese international students have changed a few habits that made it difficult for them, as shown in chart 1 below.

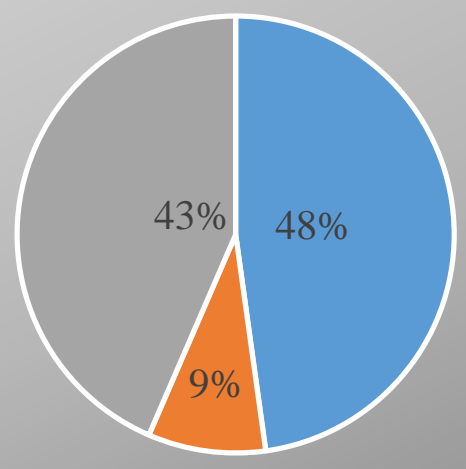

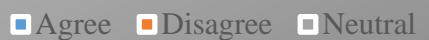

Figure 1: Vietnamese students' tendency to live with Vietnamese people leads to a lack of contact with Japanese culture 


\section{GENERAL MANAGEMENT}

From the results of the figure above (Figure 1), quite a lot of people think that living with Vietnamese people affects learning and cultural absorption in Japan.

Cho \& Morris (2015) said that cultural adaptation refers to foreigners changing their living and working habits to integrate with their culture. Expats vary in their degree of adaptation, as some places require more adjustment than others. For example, Vietnamese students in the chart above (Figure 1) will gradually need time to adapt to the new culture. Nevertheless, there will also be students who feel that the Vietnamese environment is too "cozy" they will forever be stuck in that cocoon (Cho \& Morris, 2015).

Students who come to Japan for the first time think that Japanese people overthink about the object and then just silently smile without saying their thoughts. In fact, many people know how secretive Japanese people are before coming to Japan, but many think it will be difficult for them to get along because it is difficult to know whether they like or hate them. However, over time, through the process of selfstudy and experience, they gradually understand how the Japanese work and behave, as shown in the table below (Table 2).

\begin{tabular}{|l|l|l|l|l|l|l|l|l|l|}
\hline The Way Japanese People Think & $\mathbf{1}$ & $\mathbf{2}$ & $\mathbf{3}$ & $\mathbf{4}$ & $\mathbf{5}$ & $\begin{array}{l}\text { Total } \\
\text { Reply }\end{array}$ & $\begin{array}{l}\text { Total } \\
\text { Score }\end{array}$ & $\begin{array}{l}\text { Average } \\
\text { Level }\end{array}$ \\
\hline $\begin{array}{l}\text { 1. Evaluate people according to the business, the } \\
\text { company that person works for }\end{array}$ & 1 & 4 & 11 & 4 & 3 & 23 & 73 & 0.16 \\
\hline $\begin{array}{l}\text { 2. Training style and corporate culture for new } \\
\text { employees right after recruitment }\end{array}$ & 1 & 2 & 1 & 14 & 5 & 23 & 89 & 0.19 \\
\hline $\begin{array}{l}\text { 3. Politeness exists only in the personal sphere } \\
\text { and is not universal in social relations at all }\end{array}$ & 4 & 5 & 4 & 7 & 3 & 23 & 69 & 0.15 \\
\hline $\begin{array}{l}\text { 4. Extremely self-contained when dealing and } \\
\text { communicating with foreigners }\end{array}$ & 1 & 5 & 7 & 6 & 4 & 23 & 76 & 0.17 \\
\hline $\begin{array}{l}\text { 5. They rarely look directly at each other when } \\
\text { talking }\end{array}$ & 3 & 4 & 8 & 7 & 1 & 23 & 68 & 0.15 \\
\hline $\begin{array}{l}\text { 6. Emphasis on strict vertical relationships } \\
\text { between young and old, superiors and } \\
\text { subordinates }\end{array}$ & 1 & 1 & 8 & 8 & 5 & 23 & 84 & 0.18 \\
\hline Total & & & & & & & 459 & 1.00 \\
\hline
\end{tabular}

Table 2: Japanese attitudes about behavior

Among the questions in the table above (Table 2), questions 2 and 6 received a lot of agreement from the respondents. Thuong (2017) also believes that the hierarchy is hierarchical: Confucianism was introduced to Japan very early, combined with the spirit of honoring the martial arts community to the top, creating a Japanese-style society, with the upholding of Ceremony - Trust - Meaning - Wisdom - Humanity and that spirit is still expressed very strongly through the relationships showing the hierarchical order between superiors - subordinates, company - company. Question 5 in the table above (table 2) generates mixed responses. The fact that Japanese people rarely look at each other's faces when chatting may depend on many different factors (relationships, situations, communication environment).

In the case of question 4, it should be noted that Japanese people tend to only associate with Japanese people in relation to their behavior. Due to the specific geographical location, the concept of "we" (meaning Japanese people) and the concept of "they" (meaning non-Japanese people) are permanently imprinted in the subconscious of Japanese people, so integration will not be effective. It is a simple matter and it will take time for the Japanese to become more open-minded.

Directly experiencing how Japanese people behave is a bit of a luxury for Vietnamese students. However, there are many means for Vietnamese students to better understand the Japanese code of conduct as the chart below (Figure 2)

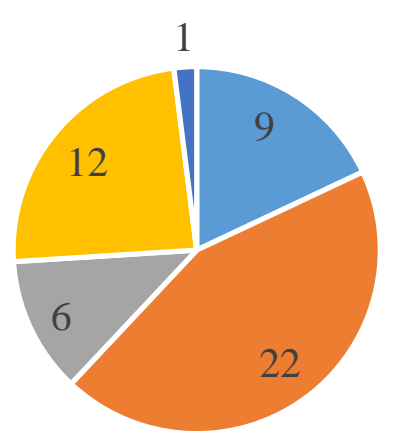

- Magazine

- Former Japanese student
- Internet

- Teacher/lecturer

Figure 2: Tool to learn about Japanese behavioral culture 


\section{GENERAL MANAGEMENT}

Nearly half of the respondents in the chart above (Figure 2) learn about culture online. However, some information will not be accurate to reality on the internet, so viewers need to know how to be selective. The majority of people surveyed are students, so asking the lecturer is also a possible method.

Through a face-to-face interview conducted via Zalo and Facebook, the question was asked: "How do you think the rules of conduct affect Vietnamese international students in Japan?" and through this face-to-face interview, the respondents' thoughts and concerns were expressed. Many of them mentioned that the code of conduct affects Vietnamese students' lifestyle, study, and activities in Japan. Moreover, affect the image of Vietnamese people in the eyes of Japanese people.

\section{Solutions}

Murphy \& Shigematsu (2002) suggest that a brief therapy of cognitive and behavioral nature with the aim of correcting the behaviors and thinking patterns of international students may be a reasonable solution. Accordingly, the awareness of relativity in behavioral culture will be the basis of improving students' ability to accept the differences that exist in the subconscious mind before coming to Japan with the things they are dealing with. Students will identify things they can try to do on their own and ways they simply have to accept the reality of the situation. In other words, it is like changing the water in an aquarium, people never change all the water in the tank, but always keep about $30-40 \%$ of the old water in the tank so that the fish does not get strange. From there, the students can separate the rules of behavior that they cannot accept from the things they can and then gradually adapt (Hoi, 2020). Such an approach can help Vietnamese students have a more positive view of Japanese social and behavioral culture and at the same time reduce stereotypes in the way of assessing Japanese people on an individual basis (Lee, 2017).

Another solution being applied by many study abroad centers is a training program to prepare international students for the difficulties and expected behaviors in Japan. If students can recognize the big difference in behavior between the two countries before coming to Japan, they will be better able to adapt.

\section{Conclusion}

The Code of Conduct is a part of society, contributing to creating sustainable relationships, measuring the civility of each employee and contributing to building a modern and professional working environment. Dealing with people is an art that brings a person who has a low level of language and literature to become intensely successful. In Japan, the culture of behavior has gone beyond the usual standards and become a characteristic of the people here. Daily eating and drinking as well as how to write letters, visit each other also have their own rules. The Japanese are very special, their disparaging words make listeners feel comfortable and their smiles make many people feel immensely embarrassed. In Japanese businesses, behavior culture is a must because it dramatically affects work efficiency and is its face. That is why many places train employees on how to behave from the first days of being a member of the business. In the case of Vietnamese students when coming to Japan, difficulties in the new environment will be inevitable such as cultural and language barriers. However, if you know how to behave like a Japanese, it will greatly shorten the time to adapt to the new environment and create a place for yourself in society.

\section{Limitations}

The article is limited and there are many things that need to be improved.

\section{Acknowledgement}

I would like to thank the lecturers who helped me to complete this article and the students who took the time and provided valuable data so that I could complete the article.

\section{References}

[1] Phạm, V. N. (2002). Văn hóa ứng xử của người Nhật thể hiện qua thái độ, cử chỉ-hành động và ngôn ngữ. Đề tài nghiên cứu khoa học, Đại học Quốc gia Hà Nội, Việt Nam.

[2] Quang, N. D., \& Hà, N. T. N. (2018). Nghiên cứu về văn hóa ứng xử học đường và giáo dục văn hóa ứng xử học đường. Tạp chí khoa học giáo dục việt nam, (2),13-17.

[3] Trần, T. H. T. (2017). Văn hóa ứng xử trong doanh nghiệp Nhật Bản: Khóa luận tốt nghiệp (Doctoral dissertation, Trường ĐH Bà Rịa-Vũng Tàu. Viện Ngôn ngữ-Văn hoá-Quan hệ Quốc tế).

[4] Lee, J. S. (2017). Challenges of international students in a Japanese university: Ethnographic perspectives. Journal of International Students, 7(1), 73-93.

[5] Hoi, H. T. (2019). Using Social Networks for English Teaching and Learning. Proceedings of the 2019 2nd Artificial Intelligence and Cloud Computing Conference. doi: $10.1145 / 3375959.3375977$

[6] Cho, J., \& Morris, M. W. (2015). Cultural study and problemsolving gains: Effects of study abroad, openness, and choice. Journal of Organizational Behavior, 36(7), 944-966. doi:10.1002/job.2028

[7] Nguyet, N.T.M. (2020). Status of student behavioral culture: a case study at hanoi national university of education. Tạp chí khoa học đại học tân trào, 19, 103-107.

[8] Tan, H. H. (2019). The Applications of Artificial Intelligence and the Abilities of Supporting in Learning Japanese Language. Proceedings of the 2019 2nd International Conference on Computational Intelligence and Intelligent Systems. doi:10.1145/3372422.3372435

[9] Murphy-Shigematsu, S. (2002). International Journal for the Advancement of Counselling, 24(1), 19-30. doi:10.1023/a:1015076202649 